JOURNAL OF SECURITY AND SUSTAINABILITY ISSUES

ISSN 2029-7017 print/ISSN 2029-7025 online

2019 September Volume 9 Number 1

http://doi.org/10.9770/jssi.2019.9.1(24)

Scopus

\title{
TOWARDS SUSTAINABLE FUNCTIONING OF ORGANIZATION: WOMEN EMPOWERNMENT AND CORPORATE MANAGEMENT CULTURE
}

\author{
Thanasuwit Thabhiranrak ${ }^{1}$, Kittisak Jermsittiparsert ${ }^{2,3 *}$ \\ ${ }^{1}$ Faculty of Management Science, Suan Sunandha Rajabhat University, Bangkok, Thailand \\ ${ }^{2}$ Department for Management of Science and Technology Development, \\ Ton Duc Thang University, Ho Chi Minh City, Vietnam \\ ${ }^{3}$ Faculty of Social Sciences and Humanities, Ton Duc Thang University, Ho Chi Minh City, Vietnam \\ E-mails: ${ }^{1}$ thanasuwit.th@ssru.ac.th; ${ }^{2 *}$ kittisak.jermsittiparsert@tdtu.edu.vn (corresponding author)
}

Received 12 January 2019; accepted 27 June 2019; published 30 September 2019

\begin{abstract}
The purpose of this study is to examine the impact of women empowerment through board diversity along with governance variables on capital structure and leverage dimensions. To achieve this objective, sample of 35 business firms over 2012-2016 is collected in the region of Thailand. Secondary data approach is implemented with descriptive and regression analysis. It is found that board diversity (presence of female members) is significantly associated to capital structure and leverage pattern. With the presence of firm age, fixed payments and risk factor, this effect is found to be true for total loan and leverage factors but insignificant for the debt to equity ratio. Effect of board size on capital structure and leverage dimensions is also found to be significant. Meanwhile, effect of age on debt ratio and total loan is positively significant but negatively significant for total leverage. Practical significance of the study covers managerial implication in the field of corporate governance and risk-taking behavior through capital structure and leverage.
\end{abstract}

Keywords: women empowerment, capital structure, corporate governance, leverage

Reference to this paper should be made as follows: Thabhiranrak, T.; Jermsittiparsert, K. 2019. Towards sustainable functioning of organization: women empowernment and corporate management culture, Journal of Security and Sustainability Issues 9(1): $321-332$. http://doi.org/10.9770/jssi.2019.9.1(24)

JEL Classifications: D24, G3

\section{Introduction and Background}

For business firms and economy, reasonable consensus is available for the significance of corporate governance $(\mathrm{CG})$ as it attains much attention in the literature. Recent studies in this field indicates the fact that success factors of business organization is closely associated to CG. The key focus of vast body of literature is on governance mechanism and its impact on the firm performance (Conyon \& He, 2008; La Rocca, Montalto, La Rocca, \& StaglianÃ, 2017; Zulkifli, Shukor, \& Rahman, 2018; Muma, 2018; Mungwari, 2018; Muniisvaran \& Vijayalakshmi, 2018; Muñoz, 2017; Myambo \& Munyanyi, 2017; Sbaouelgi, 2018; Obiekwe, 2018; Arora \& Sharma, 2016; Azeez, 2015; Francis, Hasan, \& Wu, 2015; Hasanudin et al., 2019; Esenyel \& Emeagwali, 2019).

Business firms working with the weak governance structure have more intensity to face the agency issue, where managers place their personal interest ahead of corporate interest (Bosse \& Phillips, 2016). Under the title of agency theory, it is explained that mangers are not very much careful about the funds of stakeholders, comparatively to their own (Letza, Sun, \& Kirkbride, 2004). Another theory indicates the strong association between the organizational success and satisfaction of shareholders is stewardship theory. Various dimensions 
are presented in the literature to cover the basic idea of corporate governance. In this regard, total members in the board expresses the size. It is believing that larger board size can significantly manage the business strategic affairs, comparatively to smaller board size. However, the factor of women empowerment is under observation since last couple years due to its worth in the board through gender diversification. Diversity in the board through gender specifies its impact on the performance (Bear, Rahman, \& Post, 2010; Bernardi, Bean, \& Weippert, 2002; Boulouta, 2013; Erhardt, Werbel, \& Shrader, 2003), but the literature contribution for the women empowerment through board diversification and its linkage to capital structure and leverage is very limited. Women empowerment indicates the actions and raising of status for the female through education, literacy, and job opportunities in the society (Mosedale, 2005; Malimi, 2017; Mohiuddin, 2018; Mokgari \& Pwaka, 2018).

In addition, capital structure reflects the financing decision of the business to finance its capital investment projects through debt and equity. Higher portion of debt refers to more usage of external loans with increasing amount of fixed obligations over business. While equity financing indicates the patterns of financing where more funds are availed through issuance of common and preferred shares in the market. One of fundamental point of discussion for the capital structure is leverage which defines the utilization of fixed payment obligations in a way that both risk and return in the business can magnify. Leverage specifies the relationship between sales and operating profit (operating leverage), and between operating profit and earnings per share (financial leverage). Overall leverage adds both the operating and financial leverage. The purpose of this study is to examine the effect of women empowerment through board diversity and governance dimensions on capital structure and leverage of selected firms in Thailand. Besides, effect of firm age, fixed payment ratios, and risk is also evaluated with the governance variables on capital structure and leverage. The rest of the paper is as follows. Next section covers the literature work on the topic. Section three examples the variables and their operational measurement. Section four explains the methods and econometric equations. Section five provides empirical findings and discussion. Last section indicates the conclusory part.

\section{Literature Review}

The dynamics of capital structure choice and its association with the corporate governance has provided limited empirical evidence. Research study conducted by (Morellec, Nikolov, \& Schürhoff, 2012) have empirically developed a dynamic model to explore the association between the conflict of shareholders \& manager, based on the choice of capital structure. Research study conducted by (Liao, Mukherjee, \& Wang, 2015) have indicated the fact that higher level of financial leverage in the business with the more adjustment through shareholder's desire is highly associated to better quality of CG. Quality of CG is highly linked to the independent of CEO and greater presence of outside directors in the business. However, it is also found that effect of CG on level of leverage is more pronounced with the initial level of leverage.

As per the findings of trade-off theory, value of the firm is maximum in the form of shareholders wealth when the capital structure of the business reach to the optimal level. This benefit is associated to the tax benefits against the financial distress and cost of debt. Besides, deviation from the level of leverage which is known as optimal can create significant benefit to the business. Some studies have found misbalancing or incomplete leverage rebalancing, based on refinancing cost (Lemmon, Roberts, \& Zender, 2008). Research work by (Francis et al., 2015) examines the impact of directors from the academic background and performance of the firm. It is expressed that those directors who entitled as professor can play their significant role in governance structure. Meanwhile higher stock price, lower compensation for the CEO and higher CEO turnover is highly associated to each other. During the period of last decade, (Wen, Rwegasira, \& Bilderbeek, 2002) examine the effect of corporate governance indicators and level of capital structure for listed firms in China. It is observed that if business manager tends to pursue lower value of financial leverage, when they have stronger background from board members. This relationship is only acceptable when there is a presence of board composition and tenure of CEO. However, defined association is insignificant with the presence of board size and fixed compensation for CEO.

Kang, Cheng, and Gray (2007) considers the corporate governance, board diversity and factor of independence from the context of Australian companies. Authors explains that most of the studies in stated context covers 
US region, hence cannot be generalized. (Chow, Muhammad, Bany-Ariffin, \& Cheng, 2018) examine the moderating effect of corporate governance for the relationship between capital structure of the firm and regional economic uncertainty. For this purpose, they have applied two step generalized method of moment regression approach for a sample of 907 listed firms during 2004-2014. Findings of their study reflects the fact that significant \& negative effect of regional economic indicator on capital structure with the presence of $\mathrm{CG}$ as moderator. Their findings suggest that CG is playing its role as an active mechanism during the time of higher uncertainty. Practical implication of the study reveals that policy makers can formulate the policies to mitigate the adverse effect of regional uncertainties (Zandi \& Haseeb, 2019).

Hussainey and Aljifri (2012) examine the impact of CG on financial decision of the business firms in United Arab Emirates (UAE). Specifically, their study explores the internal structure of CG and how external structure of CG can influence on capital structure. Through multiple regression models for 71 listed firms it is found that institutional investors are significantly and negatively affecting the debt to equity ratio for selected firms. However, their findings are not supporting the active monitoring assumption. Empirical analysis also indicates practical implication for the financial firms working in the region of UAE. As per the best knowledge of authors, it is found that no study is yet to be conducted for the association between CG and capital structure in UAE. La Rocca (2007) explores the relationship between corporate governance and capital structure for the value of selected firms through synthetic review of present literature and conceptual discussion. Dimitropoulos (2014) conducts their survey for CG, capital structure from European context. While some other studies have also examined the similar relationship in both developed and developing economies (Sheikh \& Wang, 2012; Boateng, Cai, Borgia, Gang Bi, \& Ngwu, 2017; Li, Pike, \& Haniffa, 2008; Majumdar \& Chhibber, 1999; Reddy \& Locke, 2014; Suto, 2003; Hussain, Abidin, Ali, \& Kamarudin, 2018; Tran et al., 2019). To the best of author's findings, existing literature is lacking with the empirical contribution from the context of women empowerment through board diversity, CG indicators, capital structure and leverage dimensions in Thailand. This study is trying to fill this gap through empirical assessment of stated variables.

\section{Definition of Variables}

Details of all variables are as follows:

\section{Capital structure (CS)}

- Capital structure is main dependent variable, referring the mixture of debt and equity in the balance sheet. To reflect the concept of capital structure, two dimensions under the title of debt ratio and log of total loans in the business are added in econometric models. Debt ratio measures the portion of long terms funds, being used to finance the capital assets. Total loans reflects overall value major loans availed by the business from available sources, where it has to pay interest over regular intervals.

\section{Leverage (LEV)}

- Leverage refers to the utilization of fixed cost in the business to increase risk and return. Higher leverage means more risk in the business and ultimately more return over equity. Two major components of leverage are presented in existing literature; operating and financial. Operating leverage measures the relationship between sales and earnings before interest and tax. While financial leverage explains the association between EBIT and EPS.

\section{Corporate Governance (CG)}

- Corporate governance explains overall rules and regulations to govern and run the business firm. It considers the board structure through size of board or number of members in the board, diversity of the board through gender categories, number of outside directors, and non-executive directors. All these measures are considered in the study, specifically board diversity through both male and female members. This factor of diversity indicates the women empowerment and overall corporate culture to strength the women in business firms for a positive image. 


\section{Firm Age (FAGE)}

- Firm age refers to the time period business is working through its operational activity in the marketplace. It is a common notion that business firms with older age have more experience comparatively to those which are new in the market. Age factor is measured with total number of years from date of incorporation to present.

\section{Fixed payment Ratios}

- With the presence of debt and equity financing in the business, fixed payments becomes integral obligations to satisfy on time. For debt, the most common type of fixed payment ratio is interest coverage ratio, reflecting the business ability to satisfy its interest payments through EBIT. At second, fixed payment covered ratio combines the fixed cost like interest, dividend, lease and principal repayment of the loan over time. In addition, dividend payout ratio measures the firm capacity to pay dividend per share to its shareholders while taking the EPS as base.

\section{Risk}

- The factor of risk reflects the chance of uncertainty for the firm. Various measures are presented in the literature to cover the title of risk. Present study considers the liquidity measure which explains the ability of the firm to meet its short-term financial obligation at the time when they becomes due. More liquid firms are supposed to stable in financial dimensions.

\section{Data, Methods and Equations}

Data for the empirical analysis is collected from annual reports of 35 companies, along with other online sources, covering the dimensions of governance structure, capital structure, leverage and fixed payment ratios. Selected firms are from the manufacturing sector in Thailand. Only those firms are selected which have no missing observation over simple period. Due to secondary in nature and quantitative, present study has applied descriptive and regression analysis, for the following econometric equations:

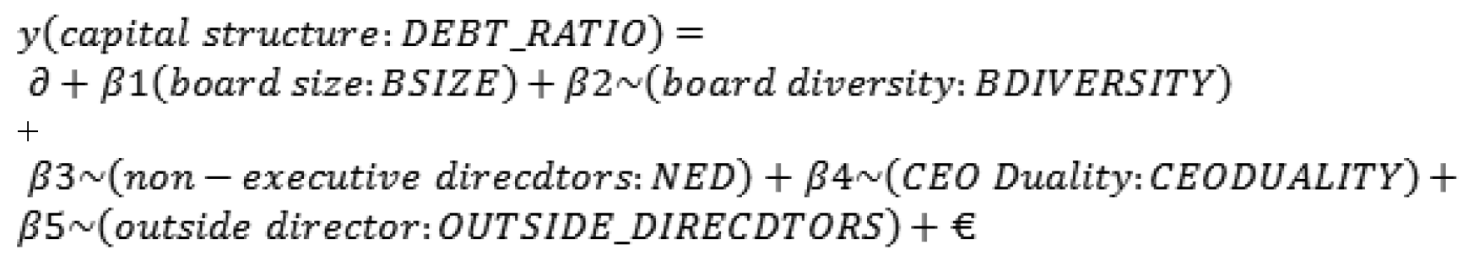

\section{Equation 1}

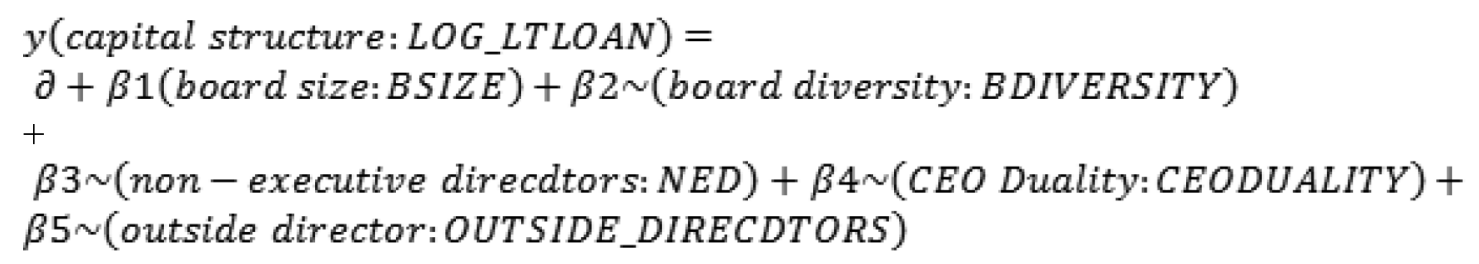

\section{Equation 2}

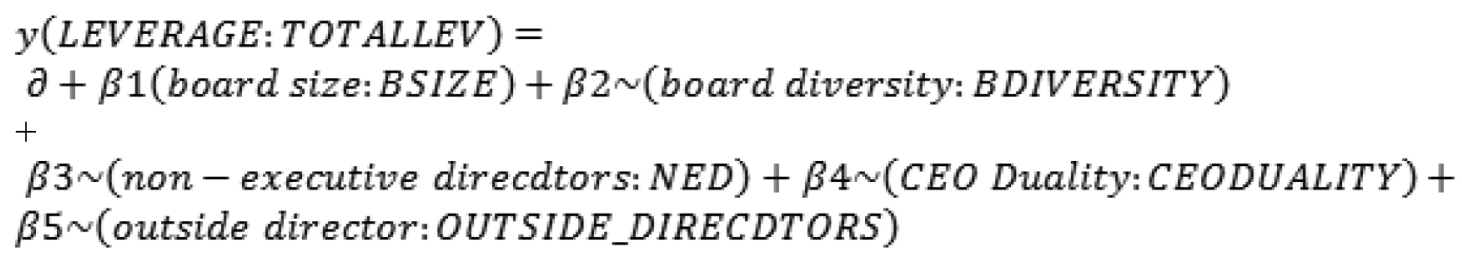

\section{Equation 3}


$y($ LEVERAGE: FINANCIALLEV) $=$

$\partial+\beta 1$ (board size: BSIZE) $+\beta 2 \sim($ board diversity: BDIVERSITY)

$+$

$\beta 3 \sim($ non - executive direcdtors: $N E D)+\beta 4 \sim($ CEO Duality: CEODUALITY $)+$ $\beta 5 \sim$ (outside director: OUTSIDE_DIRECDTORS)

Equation 4

$y$ (LEVERAGE: OPERATINGLEV) $=$

$\partial+\beta 1($ board size: BSIZE $)+\beta 2 \sim($ board diversity: BDIVERSITY $)$

$+$

$\beta 3 \sim($ non - executive direcdtors: NED $)+\beta 4 \sim($ CEO Duality: CEODUALITY $)+$

$\beta 5 \sim$ (outside director: OUTSIDE_DIRECDTORS)

Equation 5

$y\left(\right.$ capital structure $\left.: D E B T_{-} R A T I O\right)=$

$\partial+\beta 1($ firm age: $F A G E)+\beta 2($ interest payment ratio:INTEREST_P_RATIO $)+$

$\beta 3($ dividend payout ratio: $D P R)+\beta 4($ fixed payment covered ratio: $F P C R)+\beta 5($ risk $)+$

$+\beta 6 \sim$ (board diversity: BDIVERSITY)

$+$

$\beta 7$ (board size: $B S I Z E)+\beta 8 \sim($ non - executive direcdtors: $N E D)+$

$\beta 9 \sim($ CEO Duality: CEODUALITY $)+\beta 10 \sim($ outside director: OUTSIDE_DIRECDTORS $)+€$

Equation 6

$y\left(\right.$ capital structure: $\left.L O O_{-} L T L O A N\right)=$

$\partial+\beta 1($ firm age: $F A G E)+\beta 2($ interest payment ratio:INTEREST_P_RATIO $)+$

$\beta 3($ dividend payout ratio: $D P R)+\beta 4($ fixed payment covered ratio: $F P C R)+\beta 5($ risk $)+$ $+\beta 6 \sim$ (board diversity: BDIVERSITY)

$+$

$\beta 7$ (board size: $B S I Z E)+\beta 8 \sim($ non - executive direcdtors: $N E D)+$

$\beta 9 \sim($ CEO Duality: CEODUALITY $)+\beta 10 \sim($ outside director: OUTSIDE_DIRECDTORS $)+€$

Equation 7

$y($ LEVERAGE: TOT ALLEV $)=$

$\partial+\beta 1($ firm age: $F A G E)+\beta 2($ interest payment ratio:INTEREST_P_RATIO) +

$\beta 3($ dividend payout ratio: $D P R)+\beta 4($ fixed payment covered ratio: $F P C R)+\beta 5($ risk $)+$ $+\beta 6 \sim$ (board diversity: BDIVERSITY)

$+$

$\beta 7$ (board size: $B S I Z E)+\beta 8 \sim($ non - executive direcdtors: $N E D)+$

$\beta 9 \sim($ CEO Duality: CEODUALITY $)+\beta 10 \sim($ outside director: OUTSIDE_DIRECDTORS) $+€$

Equation 8

$y(L E V E R A G E:$ FINANCAILLEV) $=$

$\partial+\beta 1($ firm age: $F A G E)+\beta 2($ interest payment ratio:INTEREST_P_RATIO $)+$

$\beta 3($ dividend payout ratio: $D P R)+\beta 4($ fixed payment covered ratio: $F P C R)+\beta 5($ risk $)+$ $+\beta 6 \sim$ (board diversity: BDIVERSITY)

$+$

$\beta 7$ (board size: $B S I Z E)+\beta 8 \sim($ non - executive direcdtors: $N E D)+$

$\beta 9 \sim($ CEO Duality: CEODUALITY $)+\beta 10 \sim($ outside director: OUTSIDE_DIRECDTORS $)+€$

Equation 9 
$y($ LEVERAGE: OPERATINGLLEV $)=$

$\partial+\beta 1($ firm age: $F A G E)+\beta 2($ interest payment ratio:INTEREST_P_RATIO $)+$ $\beta 3($ dividend payout ratio: $D P R)+\beta 4($ fixed payment covered ratio: $F P C R)+\beta 5($ risk $)+$ $+\beta 6 \sim$ (board diversity: BDIVERSITY)

\section{$+$}

\section{$\beta 7$ (board size: $B S I Z E)+\beta 8 \sim($ non - executive direcdtors: $N E D)+$ $\beta 9 \sim($ CEO Duality: CEODUALITY $)+\beta 10 \sim($ outside director: OUTSIDE_DIRECDTORS $)+€$}

\section{Equation 10}

Equation 1 to 5 examines the relationship between governance indicators, capital structure and leverage. While equation 6 to 10 indicate the impact of firm age, fixed payment ratios, risk and capital structure indicators on capital structure and leverage.

\section{Results and Discussion}

Table 1 expresses descriptive findings through mean score, deviation in the average value, and range of data. Table 2 presents variables. Overall observations for the variables are 210, reflecting no missing observation during time period of interest. For Debt Ratio, average value is 44.891 , indicating the fact that most of the firm relies on the 45 percent portion of debt in their total asset's investment. Deviation in mean score of debt ratio is 2.55 with minimum of 36 and maximum of 56. For log of loan, overall value of long-term debt in the balance sheet of selected firms is observed. Average value is 4.26 while taking the natural log of the data, with the deviation of .620 and maximum value of 6.984. In capital structure decision, factor of leverage plays its significant role as it is associated to the fixed cost payments and magnification of risk_retun. Average score of total leverage is 4.058 with the deviation of 1.88. While financial leverage deals with the EBIT and earnings per share. Average value for financial leverage is 6.20 with the standard deviation of .915. For operating leverage, relationship between sales and EBIT is observed over time period of interest. Firm age indicates the time period since business is operating in the market place. Higher the firm experience means more expertise and better competitive advantages over rivals under regular course of action. Average score for the firm age is 15.652 with the deviation of .515. In addition, interest payment ratio (INTEREST_P O), average intensity of the firm to pay interest cost is 6.578 through its operating profit or EBIT. Higher this ratio means more payment for the fixed cost like Interest. For dividend payout ratio (DPR), fixed expense on equity share is observed. Average score for DPR is 4.321 with the deviation of .89. In addition, the factor of fixed payment covered ratio represents all payments which are fixed in nature and firm's intensity to pay them all. An average value of FPCR is 4.774 with the highest deviation, comparatively to all other variables. The factor of risk has an average score of 3.049 reflecting the relative value of uncertainty for all the selected firms. For corporate governance, variables like board size (BSIZE), board diversity (BDIVERSITY), non-executive directors (NED), duality of CEO (CEODUALITY), and outside directors (OUTSIDE_DI S). Board diversity reflects the factor that how much female members are added in the board by the business for better strategic decision through gender variety. Maximum four female members are found in the board size with the deviation from the mean is .839. Non-executive directors or NED reflects number of outside directors in the board.

Table 1. Descriptive Statistics

\begin{tabular}{|c|c|c|c|c|c|}
\hline Variable & Obs & Mean & Std.Dev. & Min & 36 \\
\hline DEBTRATIO & 210 & 44.891 & 2.552 & 3.89 & 6.984 \\
\hline LTLOAN & 205 & 4.2600 & .6200 & 2.31 & 5.617 \\
\hline TOTALLEV & 210 & 4.058 & 1.882 & -2.486 & 3.547 \\
\hline FINANCIALLEV & 210 & 6.2031 & .915 & -1.835 & 12.364 \\
\hline OPERATINGLEV & 210 & 3.405 & 1.473 & 6 & 21 \\
\hline FAGE & 210 & 15.652 & .515 & 2.965 & 7.983 \\
\hline
\end{tabular}




\begin{tabular}{|c|c|c|c|c|c|}
\hline DPR & 210 & 4.321 & .89 & 1.972 & 0 \\
\hline FPCR & 210 & 4.774 & 7.465 & 0 & 284.17 \\
\hline RISK & 210 & 3.049 & 2.944 & 5 & 324.17 \\
\hline BSIZE & 210 & 8.657 & 2.028 & .83 & 4 \\
\hline BDIVERSITY & 210 & .371 & 1.36 & 1 & 5 \\
\hline NED & 210 & 3.052 & .501 & 0 & 1 \\
\hline CEODUALITY & 210 & .486 & .824 & 2 & 4 \\
\hline
\end{tabular}

Correlation between firm age (FAGE) and INTEREST_P_RATIO is .151, significant at 5 percent. Significant and weak association is experienced between DPR and FAGE, between BSIZE and FAGE, between BDIVERSITY and FAGE. While negative and weak association is significant at 1 percent between BDIVERSITY and BSIZE under full sample. For OUTSIDE_DIRECTORS and BSIZE correlation is .149, significant at 5 percent level of significance. Overall problem of high correlation is analyzed through VIF as presented under table 3. For all the explanatory variables, VIF is between the range of 1-2 and maximum VIF is 1.137. While average VIF is observed at 1.067. Meanwhile, tolerance value for each of the variable is below .10, indicating no problem for high correlation, hence all factors can be considered for the further analysis.

Table 2. Variables

\begin{tabular}{|c|c|c|c|c|c|c|c|c|c|c|}
\hline VARIABLES & $(1)$ & $(2)$ & $(3)$ & $(4)$ & $(5)$ & $(6)$ & (7) & (8) & (9) & (10) \\
\hline (1) FAGE & 1.000 & & & & & & & & & \\
\hline 2) INTEREST_P_RATIO & $0.151^{* *}$ & 1.000 & & & & & & & & \\
\hline & 0.028 & & & & & & & & & \\
\hline (3) DPR & $0.195^{* * *}$ & -0.026 & 1.000 & & & & & & & \\
\hline & 0.005 & 0.708 & & & & & & & & \\
\hline 4) FPCR & 0.267 & -0.024 & -0.634 & 1.000 & & & & & & \\
\hline & 0.996 & 0.727 & 0.995 & & & & & & & \\
\hline 5) RISK & 0.116 & 0.012 & 0.017 & 0.010 & 1.000 & & & & & \\
\hline & $0.093^{*}$ & 0.864 & 0.812 & 0.890 & & & & & & \\
\hline 6) BSIZE & $-0.171^{* *}$ & -0.067 & 0.019 & 0.006 & -0.076 & 1.000 & & & & \\
\hline & 0.013 & 0.337 & 0.785 & 0.932 & 0.271 & & & & & \\
\hline 7) BDIVERSITY & $0.135^{*}$ & 0.037 & 0.008 & -0.122 & -0.033 & $-0.276^{* * *}$ & 1.000 & & & \\
\hline & 0.051 & 0.590 & 0.912 & 0.077 & 0.630 & 0.000 & & & & \\
\hline (8) NED & -0.022 & 0.004 & -0.020 & -0.021 & -0.098 & 0.029 & 0.050 & 1.000 & & \\
\hline & 0.753 & 0.954 & 0.773 & 0.757 & 0.158 & 0.675 & 0.471 & & & \\
\hline (9) CEODUALITY & 0.018 & 0.061 & -0.116 & 0.047 & 0.091 & -0.000 & -0.021 & -0.087 & 1.000 & \\
\hline & 0.795 & 0.379 & 0.092 & 0.496 & 0.189 & 0.998 & 0.757 & 0.211 & & \\
\hline (10) OUTSIDE_ & -0.025 & -0.096 & 0.079 & 0.015 & -0.075 & $0.149^{* *}$ & -0.039 & 0.099 & -0.084 & 1.000 \\
\hline DIRECTORS & 0.717 & 0.164 & 0.254 & 0.830 & 0.279 & 0.031 & 0.578 & 0.152 & 0.223 & \\
\hline
\end{tabular}

Table 3. Variance Inflation Factor

\begin{tabular}{|c|c|c|}
\hline & VIF & $1 / \mathrm{VIF}$ \\
\hline BSIZE & 1.137 & .88 \\
\hline FAGE & 1.122 & .891 \\
\hline BDIVERSITY & 1.118 & .894 \\
\hline DPR & 1.067 & .937 \\
\hline OUTSIDE DIRECTORS & 1.054 & .949 \\
\hline
\end{tabular}




\begin{tabular}{|c|c|c|}
\hline RISK & 1.04 & .961 \\
\hline CEODUALITY & 1.04 & .962 \\
\hline INTEREST P RATIO & 1.039 & .962 \\
\hline NED & 1.029 & .972 \\
\hline FPCR & 1.019 & .981 \\
\hline MEAN VIF & 1.067 &. \\
\hline
\end{tabular}

Table 3 explains the effect of corporate governance indicators on capital structure indicators, along with women empowerment through board diversity. For capital structure, factors like DEBT_RATIO, LOG_LTLOAN, TOTALLEV, FINANCIALLEV, and OPERATINGLEV as observed as main dependent variables of the study. Model 1 for DEBT_RATIO indicates a significant effect of BSIZE with the coefficient of -.182. It means that more increasing board size is negatively and significantly affecting the debt portion of the firm over time. It reflects the adverse association between the governance factor through number of members in the board and loan proportion in total assets. For LOG_LTLOAN BSIZE is again negatively and significantly associated with the coefficient of -.127 and standard error of .0528. For the factor of total leverage, BISZE reflects a positive association through robust coefficient of .0557 and standard error of .0333. It means that better board size is leading to more value of total leverage, hence increasing the risk return and their magnification too. For financial and operating leverage, coefficients are .0557 and .0942 respectively. These values are also predicting the fact that increasing financial and operating leverage is observed through BSIZE. For women empowerment in the board members, board diversity is observed through addition of female members. It is found that all the proxies of capital structure except operating leverage are significantly and positively associated to BDIVERSITY. It means that board diversity through female members increasing the leverage capacity and capital structure format at the same time. For Non-executive directors NED, significant and negative influence is observed for the FINANCIALLEV with the coefficient of -.0216 and standard error of .0137. It reflects more NED in the board can lowers the value of financial leverage and vice versa. While the factor of CEO duality indicates no significant association between any of the capital structure and leverage factors. For outside directors, it is observed that negative and significant impact on TOTALLEV through coefficient of -.141 and standard error of .0566 as well. as per stated findings, Model 3 for TOTALLEV indicates highest robust \& explained variation of .359. Table 5 shows the effect of firm age, interest payment ratio, dividend payout ratio, fixed payment covered ratio, risk and corporate governance indicators on all the proxies of capital structure and leverage. It is found that firm age has a significant and positive impact on DEBT_RATIO, and LOG_LTLOAN with the coefficients of.0422 and .00553 respectively. While its effect on TOTALEV is -.00362 , indicating significant negative influence under full sample of 35 business firms. However, for financial and operating leverage, age has no significant association. The factor of interest_P_RATIO has a positive impact on LOG_LTLOAN through beta coefficient of .00977. For TOTOALLEV, coefficient is .00203 reflects that more value of total leverage is significantly depending upon INTEREST_P_RATIO. For dividend payout ratio DPR, negative influence on total loan and positive influence on total leverage is found. These findings explains that value of loan lowers with the increasing ratio of dividend payments in the business. However, for fixed payment covered ratio, none of the capital structure and leverage factor is significantly associated.

For the factor of risk, significant and negative association is found for LOG_LTLOAN with the coefficient of -.00527. With the presence of firm age, interest covered, dividend payments, fixed payments and risk factors, BDIVERISTY has a significantly negative influence on LOG_LTLOAN, and positively significance relationship with TOALLEV. For financial \& operating leverage, board diversity has a significant with the coefficient of .0558 and .0981 respectively. 
Table 4. Effect of corporate governance on capital structure indicators

\begin{tabular}{|c|c|c|c|c|c|}
\hline & $(1)$ & $(2)$ & $(3)$ & $(4)$ & $(5)$ \\
\hline VARIABLES & DEBT_RATIO & LOG_LTLOAN & TOTALLEV & FINANCIALLEV & OPERATINGLEV \\
\hline & & & & & \\
\hline & $-0.182^{* *}$ & $-0.127 * *$ & $0.215^{* * *}$ & $0.0557^{*}$ & $0.0942^{*}$ \\
\hline BSIZE & $(0.0836)$ & $(0.0528)$ & $(0.0229)$ & $(0.0333)$ & $(0.0495)$ \\
\hline BDIVERSITY & $0.296^{* * *}$ & $0.149^{* * *}$ & $0.140^{* * *}$ & $0.0389 * *$ & $(0.126$ \\
\hline & $(0.017)$ & $(0.010)$ & $(0.0512)$ & $-0058)$ & $(0.0900)$ \\
\hline NED & -0.0404 & 0.0645 & -0.00349 & $-0.0261 *$ & -0.0301 \\
\hline CEODUALITY & $(0.128)$ & $(0.0762)$ & $(0.0330)$ & $(0.0137)$ & $(0.0874)$ \\
\hline & 0.0988 & 0.0164 & -0.0199 & -0.164 & -0.195 \\
\hline OUTSIDE_DIRECTORS & $(0.351)$ & $(0.205)$ & $(0.0904)$ & $(0.129)$ & $(0.198)$ \\
\hline & 0.0135 & 0.0308 & $-0.141 * *$ & -0.00458 & -0.103 \\
\hline Constant & $(0.222)$ & $(0.117)$ & $(0.0566)$ & $(0.0241)$ & $(0.123)$ \\
\hline & $6.386^{* * *}$ & $15.18 * * *$ & $2.698 * * *$ & -0.310 & 0.0471 \\
\hline Observations & $(0.982)$ & $(0.555)$ & $(0.255)$ & $(0.280)$ & $(0.395)$ \\
\hline R-squared & 210 & 184 & 210 & 210 & 210 \\
\hline
\end{tabular}

Robust standard errors in parentheses

$* * * \mathrm{p}<0.01, * * \mathrm{p}<0.05, * \mathrm{p}<0.1$

Table 5. Effect of corporate governance on capital structure indicators

\begin{tabular}{|c|c|c|c|c|c|}
\hline & $(1)$ & (2) & (3) & (4) & (5) \\
\hline VARIABLES & DEBT_RATIO & LOG_LTLOAN & TOTALLEV & FINANCIALLEV & OPERATINGLEV \\
\hline \multirow[t]{2}{*}{ FAGE } & $0.0422 * * *$ & $0.00553^{* * *}$ & $-0.00362 * * *$ & -0.000101 & 0.000543 \\
\hline & $(7.38 \mathrm{e}-05)$ & $(0.00174)$ & $(0.000776)$ & $(0.000505)$ & $(0.000800)$ \\
\hline \multirow[t]{2}{*}{ INTEREST_P_RATIO } & $-5.75 e-05$ & $0.00977 * * *$ & $0.00203 * *$ & -0.000347 & -0.00125 \\
\hline & $(3.77 e-05)$ & $(0.00183)$ & $(0.000907)$ & $(0.000639)$ & $(0.00148)$ \\
\hline \multirow[t]{2}{*}{ DPR } & 0.000233 & $-0.285 * * *$ & $0.0655 * *$ & 0.0131 & 0.119 \\
\hline & $(0.000737)$ & $(0.0517)$ & $(0.0253)$ & $(0.0279)$ & $(0.0818)$ \\
\hline \multirow[t]{2}{*}{ FPCR } & $3.87 \mathrm{e}-05$ & 0.00887 & 0.000418 & 0.00122 & 0.00678 \\
\hline & $(2.86 \mathrm{e}-05)$ & $(0.00614)$ & $(0.000892)$ & $(0.00127)$ & $(0.00468)$ \\
\hline \multirow[t]{2}{*}{ RISK } & $-8.19 \mathrm{e}-05$ & $-0.00527 * * *$ & -0.000968 & 0.000333 & $4.61 \mathrm{e}-05$ \\
\hline & $(6.59 \mathrm{e}-05)$ & $(0.00167)$ & $(0.000937)$ & $(0.000478)$ & $(0.000680)$ \\
\hline \multirow[t]{2}{*}{ BDIVESITY } & 0.000503 & $-0.103^{*}$ & $0.200 * * *$ & $0.0558 *$ & $0.0981^{*}$ \\
\hline & $(0.000513)$ & $(0.0533)$ & $(0.0224)$ & $(0.0336)$ & $(0.0501)$ \\
\hline \multirow[t]{2}{*}{ BSIZE } & 0.00233 & -0.184 & $-0.117 *$ & 0.0953 & 0.150 \\
\hline & $(0.00151)$ & $(0.118)$ & $(0.0613)$ & $(0.0642)$ & $(0.0939)$ \\
\hline \multirow[t]{2}{*}{ NED } & -0.000577 & 0.0625 & -0.00718 & -0.0250 & -0.0245 \\
\hline & $(0.00203)$ & $(0.0733)$ & $(0.0314)$ & $(0.1308)$ & $(0.0875)$ \\
\hline \multirow[t]{2}{*}{ CEODUALITY } & 0.00444 & -0.0855 & -0.00190 & -0.165 & -0.186 \\
\hline & $(0.00554)$ & $(0.199)$ & $(0.0881)$ & $(0.131)$ & $(0.207)$ \\
\hline \multirow[t]{2}{*}{ OUTSIDE_DIRECTORS } & 0.00115 & 0.0868 & $-0.141 * * *$ & -0.00681 & -0.120 \\
\hline & $(0.00387)$ & $(0.115)$ & $(0.0541)$ & $(0.0258)$ & $(0.124)$ \\
\hline \multirow[t]{2}{*}{ CONSTANT } & $0.426^{* * *}$ & $14.25 * * *$ & $3.172 * * *$ & -0.317 & -0.132 \\
\hline & $(0.0212)$ & $(0.596)$ & $(0.277)$ & $(0.289)$ & $(0.388)$ \\
\hline Observations & 210 & 184 & 210 & 210 & 210 \\
\hline R-squared & .2800 & 0.176 & 0.430 & 0.271 & 0.0451 \\
\hline
\end{tabular}


However, factor of board size has its significant and negative impact on total leverage. For NED, and CEODUALITY no significant association is found for capital structure and leverage dimensions. In addition, outside directors has a significant and negative influence on total leverage with the coefficient of -.141. Overall explanatory power is maximum for Model 8, followed by model 6 and Model 7 respectively (Table 4). In Table 5 effect of corporate governance on capital structure indicators is presented.

\section{Conclusion and Recommendations}

This study has analyzed the effect of corporate governance variables along with women empowerment on capital structure and leverage factors. For this purpose, a sample of 35 business firms working in the region of Thailand are selected over 2012 to 2016 . Besides, effect of firm age, fixed payment ratios like interest and dividend with risk in the business is evaluated over similar time while adding the corporate governance indicators for capital structure and leverage. Pooled regression findings indicates that women empowerment in the board through board diversity indicates its significant and positive influence on debt rations, total leverage and financial leverage. But the effect on operating leverage is found to be insignificant under full sample of the study. while board size is negatively affecting the debt ratio and total debt in the business, but positive influence on total leverage, financial leverage and operating leverage. The value of financial leverage is negatively influenced by non-executive directors in the business. Through CEO duality, only effect on total leverage is significant \& negative. With the presence of firm age, risk and fixed payment ratios, significant effect is observed through female members in the board on capital structure and leverage, except for debt ratio. It is observed that more outside directors in the board negatively and significantly affecting the total leverage, hence lowering the magnification of risk and return.

These findings have provided a solid justification for theoretical and empirical contribution in the literature from the context of Thailand. More precisely, empirical literature on women empowerment and capital structure is very limited and enough gap is still available to cover. It is found that capital structure and risk-taking decision of the business are closely link to the situation when there will be female members in the BODs. The influence of female members is not neglectable due to gender diversity. Meanwhile, presented findings have their considerable implication in the field of financing decision and developing a corporate culture through mixture of board members. Business regulators and corporate strategic decision makers can review the impact of female members on leverage decision and mixture of debt and equity in the business. However, this study is based on several research limitations, providing a pathway for future research. At first sample size is limited to 35 firms only within specific region of Thailand with restricted implications outside the country. At second, advance panel models like GMM, fixed effect and random effect are also missing in the analysis part which can be reconsidered for upcoming studies.

\section{References}

Arora, A., \& Sharma, C. (2016). Corporate governance and firm performance in developing countries: evidence from India. Corporate Governance, 16(2), 420-436. Available at: https://doi.org/10.1108/cg-01-2016-0018

Azeez, A. (2015). Corporate governance and firm performance: evidence from Sri Lanka. Journal of Finance, 3(1), $180-189$.

Bear, S., Rahman, N., \& Post, C. (2010). The impact of board diversity and gender composition on corporate social responsibility and firm reputation. Journal of Business Ethics, 97(2), 207-221. Available at: https://doi.org/10.1007/s10551-010-0505-2

Bernardi, R. A., Bean, D. F., \& Weippert, K. M. (2002). Signaling gender diversity through annual report pictures: A research note on image management. Accounting, Auditing \& Accountability Journal, 15(4), 609-616. Available at: https://doi.org/10.1108/09513570210441440

Boateng, A., Cai, H., Borgia, D., Gang Bi, X., \& Ngwu, F. N. (2017). The influence of internal corporate governance mechanisms on capital structure decisions of Chinese listed firms. Review of Accounting and Finance, 16(4), 444-461.

Bosse, D. A., \& Phillips, R. A. (2016). Agency theory and bounded self-interest. Academy of Management Review, $41(2), 276-297$. Available at: https://doi.org/10.5465/amr.2013.0420

Boulouta, I. (2013). Hidden connections: The link between board gender diversity and corporate social performance. Journal of Business Ethics, 113(2), 185-197. Available at: https://doi.org/10.1007/s10551-012-1293-7 
Chow, Y. P., Muhammad, J., Bany-Ariffin, A., \& Cheng, F. F. (2018). Macroeconomic uncertainty, corporate governance and corporate capital structure. International Journal of Managerial Finance, 14(3), 301-321. Available at: https://doi.org/10.1108/ijmf-08-2017-0156

Conyon, M., \& He, L. (2008). CEO Turnover and Firm Performance in China's Listed Firms (CRI 2009-012).

Dimitropoulos, P. (2014). Capital structure and corporate governance of soccer clubs: European evidence. Management Research Review, 37(7), 658-678. Available at: https://doi.org/10.1108/mrr-09-2012-0207

Erhardt, N. L., Werbel, J. D., \& Shrader, C. B. (2003). Board of director diversity and firm financial performance. Corporate Governance: An International Review, 11(2), 102-111. Available at: https://doi.org/10.1111/1467-8683.00011

Esenyel, V., \& Emeagwali, O. (2019). The relationship between perceived corporate reputation and employee's positive word of mouth behavior: The mediation effect of trust to managers. Management Science Letters, 9(5), 673-686. http://dx.doi.org/10.5267/j. msl.2019.2.004

Francis, B., Hasan, I., \& Wu, Q. (2015). Professors in the boardroom and their impact on corporate governance and firm performance. Financial Management, 44(3), 547-581. Available at: https://doi.org/10.1111/fima.12069

Hasanudin, A.I., Yuliansyah, Y., Said, J., Susilowati, Ch., Muafi. (2019). Management control system, corporate social responsibility, and firm performance, Entrepreneurship and Sustainability Issues 6(3): 1154-1168. http://doi.org/10.9770/jesi.2019.6.3(21)

Hussain, H.I., Abidin, I.S.Z., Ali., A. \& Kamarudin, F. (2018) Debt Maturity and Family Related Directors: Evidence from a Developing Market, Polish Journal of Management Studies, 18 (2), 118 - 134.

Hussainey, K., \& Aljifri, K. (2012). Corporate governance mechanisms and capital structure in UAE. Journal of Applied Accounting Research, 13(2), 145-160. Available at: https://doi.org/10.1108/09675421211254849 .

Kang, H., Cheng, M., \& Gray, S. J. (2007). Corporate governance and board composition: Diversity and independence of Australian boards. Corporate Governance: An International Review, 15(2), 194-207. Available at: https://doi.org/10.1111/j.1467-8683.2007.00554.x

La Rocca, M. (2007). The influence of corporate governance on the relation between capital structure and value. Corporate Governance: The international journal of business in society, 7(3), 312-325. Available at: https://doi.org/10.1108/14720700710756580

La Rocca, M., Montalto, F., La Rocca, T., \& StaglianÃ, R. (2017). The effect of ownership on firm value: a meta-analysis. Economics Bulletin, 37(4), 2324-2353.

Lemmon, M. L., Roberts, M. R., \& Zender, J. F. (2008). Back to the beginning: persistence and the cross-section of corporate capital structure. The Journal of Finance, 63(4), 1575-1608. Available at: https://doi.org/10.1111/j.1540-6261.2008.01369.x

Letza, S., Sun, X., \& Kirkbride, J. (2004). Shareholding versus stakeholding: A critical review of corporate governance. Corporate Governance: An International Review, 12(3), 242-262. Available at: https://doi.org/10.1111/j.1467-8683.2004.00367.x

Li, J., Pike, R., \& Haniffa, R. (2008). Intellectual capital disclosure and corporate governance structure in UK firms. Accounting and business research, 38(2), 137-159. Available at: https://doi.org/10.1080/00014788.2008.9663326

Liao, L. K., Mukherjee, T., \& Wang, W. (2015). Corporate governance and capital structure dynamics: an empirical study. Journal of Financial Research, 38(2), 169-192. Available at: https://doi.org/10.1111/jfir.12057

Majumdar, S. K., \& Chhibber, P. (1999). Capital structure and performance: Evidence from a transition economy on an aspect of corporate governance. Public choice, 98(3-4), 287-305.

Malimi, K. (2017). The Influence of Capital Adequacy, Profitability, and Loan Growth on Non-Performing Loans a Case of Tanzanian Banking Sector. International Journal of Economics, Business and Management Studies, 4(1), 38-49.

Mohiuddin, Z. A. (2018). Effect of Lifestyle on Consumer Decision Making: A Study of Women Consumer of Pakistan. Journal of Accounting, Business and Finance Research, 2(1), 12-15.

Mokgari, M. T., \& Pwaka, O. (2018). An Evaluation of Effectiveness of Oversight Committees: A Case of City of Johannesburg, Section 79 Committees. International Journal of Public Policy and Administration Research, 5(2), 48-67.

Muma, E. C. (2018). Transformative Constitutionalism in Post-Colonial Africa: A Framework for Democracy and Human Rights Protection. International Journal of Emerging Trends in Social Sciences, 3(1), 29-45.

Mungwari, T. (2018). Centre for Language and Communication Studies, Chinhoyi University of Technology, Zimbabwe. International Journal of Social Sciences Perspectives, 2(2), 112-125. 
Muniisvaran, K., \& Vijayalakshmi, M. J. (2018). Psychological Support for Mental Health of Mothers to Childhood the Children with Disability. International Journal of Asian Social Science, 8(12), 1186-1191.

Muñoz, L. (2017). Is Environmental Externality Management a Correction of Adam Smith's Model to Make it Environmentally Friendly and Shift it Towards Green Markets or is it a Distortion on Top of another Distortion. International Journal of Economics, Business and Management Studies, 4(1), 1-16.

Myambo, A., \& Munyanyi, T. (2017). Effecetiveness of Labour Court in Labour Dispute Management in Zimbabwe. International Journal of Social and Administrative Sciences, 2(1), 15-30.

Morellec, E., Nikolov, B., \& Schürhoff, N. (2012). Corporate governance and capital structure dynamics. The Journal of Finance, 67(3), 803-848. Available at: https://doi.org/10.1111/j.1540-6261.2012.01735.x

Mosedale, S. (2005). Assessing women's empowerment: towards a conceptual framework. Journal of international development, 17(2), 243-257. Available at: https://doi.org/10.1002/jid.1212

Obiekwe, O. (2018). Human Capital Development and Organizational Survival: A Theoretical Review. International Journal of Management and Sustainability, 7(4), 194-203.

Reddy, K., \& Locke, S. (2014). The relationship between ownership structure, capital structure and corporate governance practices: A case study of co-operatives and mutuals in New Zealand. International Journal of Managerial Finance, 10(4), 511-536. Available at: https://doi.org/10.1108/ijmf-12-2012-0130

Sheikh, A. N., \& Wang, Z. (2012). Effects of corporate governance on capital structure: empirical evidence from Pakistan. Corporate Governance: The international journal of business in society, 12(5), 629-641. Available at: https://doi.org/10.1108/14720701211275569

Suto, M. (2003). Capital structure and investment behaviour of Malaysian firms in the 1990s: a study of corporate governance before the crisis. Corporate Governance: An International Review, 11(1), 25-39. Available at: https://doi.org/10.1111/1467-8683.00299

Sbaouelgi, J. (2018). Income Inequality and Economic Growth: Application of Quantile Regression. Asian Development Policy Review, 6(1), 1-14.

Tran, H., Bui, V., Phan, T., Dau, X., Tran, M., \& Do, D. (2019). The impact of corporate social responsibility and risk management on financial performance: The case of Vietnamese textile firms. Management Science Letters, 9(7), 1029-1036. http://dx.doi.org/10.5267/j. msl.2019.4.003

Wen, Y., Rwegasira, K., \& Bilderbeek, J. (2002). Corporate governance and capital structure decisions of the Chinese listed firms. Corporate Governance: An International Review, 10(2), 75-83. Available at: https://doi.org/10.1111/1467-8683.00271

Zandi, G., \& Haseeb, M. (2019). The importance of green energy consumption and agriculture in reducing environmental degradation: Evidence from sub-Saharan African countries. International Journal of Financial Research, 10(5), 215-227.

Zulkifli, N. S., Shukor, Z. A., \& Rahman, M. R. C. A. (2018). Intellectual Capital Efficiency and Firm Performance in Malaysia: The Effect of Government Ownership. Asian Journal of Accounting and Governance, 8, 93-105. Available at: https://doi.org/10.17576/ajag2017-08si-09

Thanasuwit THABHIRANRAK is the Associate Professor Dr., Vice President for Research and Development of Suan Sunandha Rajabhat University, Thailand. He graduated B.A. in Political Science (1988) from Ramkhamhaeng University, Thailand, M.B.A (1995) from National University, and D.B.A. (2002) from Argosy University, USA. His research fields are human resource management, strategic management, innovation management, entrepreneurship, and marketing.

Kittisak JERMSITTIPARSERT holds Ph.D. in Social Sciences (major in Political Science) from Kasetsart University, Thailand. He is currently a researcher at Chulalongkorn University Social Research Institute, a part-time researcher at Ton Duc Thang University, and the secretary general of the Political Science Association of Kasetsart University. His areas of expertise are democratization in Thailand, history of political thought, human resource management, international political economy, public policy analysis, social research, and transnational human trafficking.

ORCID ID: 0000-0003-3245-8705

This work is licensed under the Creative Commons Attribution International License (CC BY)

http://creativecommons.org/licenses/by/4.0/ 